\title{
Translational Repression
}

National Cancer Institute

\section{Source}

National Cancer Institute. Translational Repression. NCI Thesaurus. Code C29860.

Translational Repression consists of cellular and enzymatic reactions that inhibit the process by which polypeptides are synthesized on ribosomes from information in mRNA transcripts. 